\title{
Self Assessments of the Prospective Teachers about the Teaching Materials They Have Designed
}

\author{
Burcu Duman ${ }^{1, *}$ \\ ${ }^{1}$ Faculty of Education, Bartin University, Bartın, Turkey \\ *Correspondence: Faculty of Education, Bartin University, Bartın, Turkey. Tel: 90-378-501-1000/1172. E-mail: \\ dmn.brc@gmail.com
}

Received: October 18, 2018

Accepted: November 22, $2018 \quad$ Online Published: December 20, 2018

doi:10.5430/wje.v8n6p165

URL: https://doi.org/10.5430/wje.v8n6p165

\begin{abstract}
The purpose of the study is to reveal the self-evaluations of the prospective teachers on two-and three-dimensional visual teaching materials they have designed in the field of the pedagogical formation education. A qualitative research method was used in the study. The study group was chosen from the prospective teachers who were enrolled in the pedagogical formation education at a state university in Turkey. A questionnaire consisting of three open-ended questions was used. In this questionnaire, the prospective teachers were asked questions about the strengths and weaknesses of the instructional materials they designed and what kind of arrangements they would make if they designed the material again. The data were analyzed descriptively. The views of the prospective teachers on the strengths of the instructional materials they design are collected under seven themes: the characteristics of us, the effect on learning the relation with the subject, the preparation and construction process, the gains to the learners, the presentation of the information and conformity. The opinions of the prospective teachers about the weaknesses of the teaching materials have been collected under five themes. In general, it is seen that the arrangements to be made in the case of redesign are expressed in terms of the weaknesses.
\end{abstract}

Keywords: prospective teacher, teaching material, material design, self assessment

\section{Introduction}

It is known that different educational materials have been used in the educational activities carried out from past to present depending on the scientific and technological development level of the period. Especially in today's world ; where scientific developments continue to increase rapidly, teaching technology and materials have become one of the indispensables of educational environments. Güven (2008: 168) stated that the use of different and new teaching materials in educational environments have been emerging as well a need as a requirement of the changes in science and technology. At the same time, the models and theories that explain the factors affecting the student learning emphasize the importance of the use of materials in education (Uşun, 2012). The use of materials in education plays an important role in the success of the curriculum by preparing an effective educational environment and enabling the students to reach the foreseen goals more easily. In this respect, the preparation and use of teaching materials is one of the most emphasized skills in teaching programs in recent years (Yanpar Yelken, 2011: 10). Kablan \& Topan (2013) state that the effectiveness of the teaching programs will increase due to the use of the materials in the course. On the other hand, the fact that learning is possible only with the active participation of the learners attracts attention to the teaching materials as a factor that increases the efficiency of teaching.

While explaining the concept of instructional material, the concept of material should be defined first. The material corresponds to the instrument in the dictionary. Instruments are defined as "materials which should be used to perform a specific job" (TDK, 2018). Tools are used to make materials (Yanpar Yelken, 2011: 9). A tool becomes an instructional material if it undergoes a change or process for the achievement of the instructional objectives. For example, a blackboard is a tool. If a process, a picture, a font, a graphic etc. is created over it, it is transformed into a course material. Likewise, acetate is a tool, but if a process (information writing, drawing, problem solving, etc.) is made over it, it becomes material (Yangın, 2011: 45; Yanpar Yelken, 2011: 9). The important thing is to synthesize the tools in a creative way to realize the student achievements, to develop these syntheses using the material 
preparation and the design principles (Yanpar Yelken, 2011: 10).

Teaching material is defined as "learning and teaching aids which are generally cheap and transient, expressing the structure and order of the content of the teaching and learning activities" (Uşun, 2012: 7). The instructional material covers the course presentation content, which is made by using tools in order to achieve the objectives in general (Yanpar Yelken, 2011: 9). Teaching materials are the elements that carry information between the source and the recipient in the teaching-learning process. Therefore, it is the most important element that contributes to the learning-teaching process (Çelik, 2012: 30) and is used to support the teaching. The materials selected according to the subject and the purpose make the subject alive and enrich the learning process. The use of materials facilitates the learning and perception. The materials raise the interests of learners and increase their motivation. They attract attention and bring vitality to the class. They shorten the learning time, reinforce the knowledge and help persistence. They make it easier to remember the information learned. They contribute to the fun of the learning process. The materials are also used to provide a multi-learning environment, help learners to meet their individual needs, draw attention, embody abstract information, and enable safe observation (Çelik, 2012: 28; Çoban \& İleri, 2013; Yangın, 2011: 44).

The functions and the importance of the different teaching materials in the teaching environment are expressed in the cone of the life created by Edgar Dale (1969). According to the cone of the life; the more the number of sensory organs involved in the learning work, the better we learn and we forget that late. The best teaching is from concrete to abstract, from simple to complex, and we learn most of what we learn with the help of our eyes (Çilenti, 1984: 57). Hoban et al. (1937) draw attention to the fact that the contents of the learning must be organized from concrete to abstract and that more than one sense organ must be involved in the learning process (As cited in Yanpar \& Yıldırım, 1999: 13). In this respect, the use of the materials enables the students to learn as much as possible with more sense organs, while transforming the learning content into a concrete, more comprehensible and simple form. According to the researches about the material usage (Apperson, Laws \& Scepansky, 2006; Audrey, 2008; Cezayirli, 2014; Cohen, 1992; Kablan \& Topan, 2013; Kurtdede Fidan, 2008; Öztürk, 2012; Suydam \& Higgins, 1977), it is observed that when the materials are used in the lessons, they provide active learning, support individual learning, students' viewpoints change in a positive way and they have a positive effect on academic achievement. Students' working in the school environment and presenting the materials they prepare in the course increase the students' responsibility and the motivation for preparing the material.

The vital importance of the teaching materials in the learning process requires teachers to have the necessary qualifications in the material selection, use and design and to demonstrate these competences in practice (Yangin, 2011: 50). In order for the teachers to have the competencies to prepare the effective teaching materials, they should know the functions, benefits and limitations of the materials in the teaching environments and be aware of the issues to be considered while selecting and using the materials. In fact, one of the basic qualities teachers should have is to produce and use the materials to perform the teaching successfully (Uşun, 2012: 34). A teacher can select the ready-made instructional materials, transform the existing materials, or design the materials to meet the student-needs (Çelik, 2012: 30). The prospective teachers' designing the instructional materials not only in the knowledge level but also in the application - even in the evaluation level - will help them design the materials easily when they become teachers (Uşun, 2012: 46). In addition, the materials used in the learning- teaching process should not only be selected and prepared but also evaluated and developed after use (Yanpar Yelken, 2011: 276). In other words, only designing and using the materials should not be considered sufficient; the evaluation of the material afterwards should be considered. It is thought that the self-evaluation, which is one of the types of evaluation, will allow the prospective teachers to reflect their own performances through the designed materials.

According to Turgut and Baykul (2010), the evaluation is the process of reaching a value judgment by comparing the results of the measurement with a criterion. In this case, self-assessment can be defined as the process of reaching a judgment related to an individual by comparing a measurement result with an individual himself / herself. When the student performing a performance task evaluates his / her own performance, this not only increases his /her awareness of his work but also he / she shares his / her responsibilities of the learning with his /her teacher. This evaluation activity is also thought to serve the critical thinking skills to be gained by the students through criticizing their own performance. Self-assessment advocates argue that the learners' autonomy about the subject is supported because they take more responsibility in evaluating their own learning in this way (Mistar, 2011). According to Harris (1997), self-evaluation makes students more active and focused. According to Pierce (2003), she teaches to be independent of the teacher. Students become aware of their strengths and weaknesses, learn to look at themselves objectively, share their responsibility of whether they learn with the teacher (Falchikov, 1986; Boud, 1995; Noonan \& Randy, 2005). Teachers and the prospective teachers' evaluating the materials they design based on various criteria 
and revealing the strengths and weaknesses of the materials will guide them in designing the suitable and qualified materials, and thus improve the quality of the education. All these findings indicate the importance of designing and evaluating the instructional materials in the education of the prospective teachers.

"Instructional Technology and Material Design" (ITMD) course, one of the purposes of which is to make the teachers competent on teaching materials, is one of the compulsory classes in teacher education degree programs in Turkey. In ITMD, it is aimed for prospective teachers to gain knowledge, skills and attitudes in teaching technologies and use them in teaching, design and use of the instructional materials (YÖK, 2007). Various researches about the ITMD course show that this course contributes to the personal, professional and social development of the prospective teachers (Acer, 2011; Aslan, 2015; Bakaç \& Özen, 2016; Birişçi \& Karal, 2011; Çalışoğlu, 2015; Güneş \& Aydoğdu İskenderoğlu, 2014; Gürol, Yavuzalp, Bağçacı, \& Serhatlığlu, 2009; Johson \& Howell, 2005; Kolburan Geçer, 2010; Özer \& Tunca, 2014; Yanpar, 2009). However, in the study conducted by Güven (2006), it has been revealed that the students gained cognitive and affective behaviors with the ITMD course but they did not gain psycho-motor behaviors.

In this respect, it is thought that the prospective teachers designing two or three dimensional teaching materials can contribute to the development of the psychomotor skills. Based on this information, this study is based on the design, presentation and evaluation of two and three dimensional visual teaching materials. Considering the fact that the prospective teachers' presenting their projects in the classroom and the contributions to their professional development develop critical and creative thinking skills (Birinci 2008; Güneş \& Aydoğdu İskenderoğlu, 2014), design has not been seen adequate on its own, and the material presentation and the sample course presentations are included in the research process. Finally, self-evaluation was applied. The purpose of the study is to reveal the self-evaluations of the prospective teachers on two-and three-dimensional visual teaching materials they have designed in the field of pedagogical formation education. For this purpose, the answers to the following questions were sought;

-What are the strengths of the instructional materials they design according to the prospective teachers?

- What are the weaknesses of the instructional materials they design according to the prospective teachers?

- What kind of arrangements would the prospective teachers make if they had to re-design the teaching materials?

\section{Method}

Qualitative Qualitative research method was used in the study. The study is designed as a case study. The analysis unit determines the characteristics of the case study (Merriam, 2013: 41). The unit of analysis of this research is the self-assessment of the prospective teachers.

\subsection{Study Group}

The study group was chosen from the prospective teachers who were enrolled in the pedagogical formation education at a state university in Turkey in 2015-2016 academic year. The prospective teachers were determined by the criterion sampling which is one of the methods of purposeful sampling. The basic understanding of criterion sampling is the study of the situations that predetermine or meet a set of criteria created by the researchers (Yildirım \& Şimşek, 220, 112). In criterion sampling, the observation units can be formed from the persons with certain qualifications (Büyüköztürk et al., 2014). Being a teacher trainee of the Philosophy Group and taking the ITMD course was determined as the sampling criterion. Accordingly, 55 prospective teachers at the branch of Philosophy formed the study group.

\subsection{Data Collection Tool and Validity-Reliability Studies}

In the study, a questionnaire form consisting of three open-ended questions was used. In this form, the prospective teachers were asked questions about the strengths and weaknesses of the instructional materials they designed and what kind of arrangements they would make if they designed the material again.

In the research; Material evaluation checklist was used to increase the internal validity and to confirm the findings. This checklist was prepared using various sources (Kürüm, 2008; Yanpar Yelken, 2011; Uşun, 2012; Demirel \& Yağc1, 2012) and distributed to the prospective teachers before starting the material design process. Information was given about each criterion in the control list, which includes the measurements to be used in the material evaluation, and it was stated that these criteria should be taken into consideration while designing the materials. These criteria are; the conformity to the objectives of the course, the compliance with the student level, the conformity to the design elements and principles, providing motivation and attention, being simple, plain and comprehensible, 
importance, providing student participation, ease of use, developability, durability and soundness, repeatability, updatability, effectiveness, including correct and valid information and economy.

The research process consists of three main stages. In the first stage, the prospective teachers who have acquired theoretical knowledge about the material design in the ITMD course started to design materials simultaneously under the guidance of the instructor. In the second stage, the designed materials were presented in the class. Each prospective teacher introduced his/her material first during the presentation, and then gave a sample lecture including the use of the material. In the third phase, the prospective teachers made self-evaluations on the materials they designed. At the end, each prospective teacher scored his/her teaching material according to the criteria in the checklist (1: low, 2: medium, 3: high) and answered the open-ended questionnaire. As the concepts in the checklist reflect the conceptual framework for material design, the open-ended questionnaire was a guide for answering. The scores obtained from the control list and the answers to the open-ended questionnaire were examined. This is considered important in providing a coherent and meaningful whole and providing internal validity. The detailed explanation of all stages of the research is aimed at increasing external validity. In order to increase the reliability of the research, attention was paid to clearly expressing the research questions and research's being generally consistent with the research questions. And in the findings section, direct quotations and material photographs are given.

\subsection{Data Analysis}

The data were analyzed descriptively. Based on the research questions, a framework was created for data analysis. According to this framework, the data were read and edited, themes emerged and direct quotations were selected. Sub-themes have been shaped by explaining and understanding the findings. The findings are presented with color images. The repetition numbers of sub-themes have been written over the arrows in the image. At the same time, the arrows are shown in different thicknesses. Thus, the weights of the sub-themes have become visible.

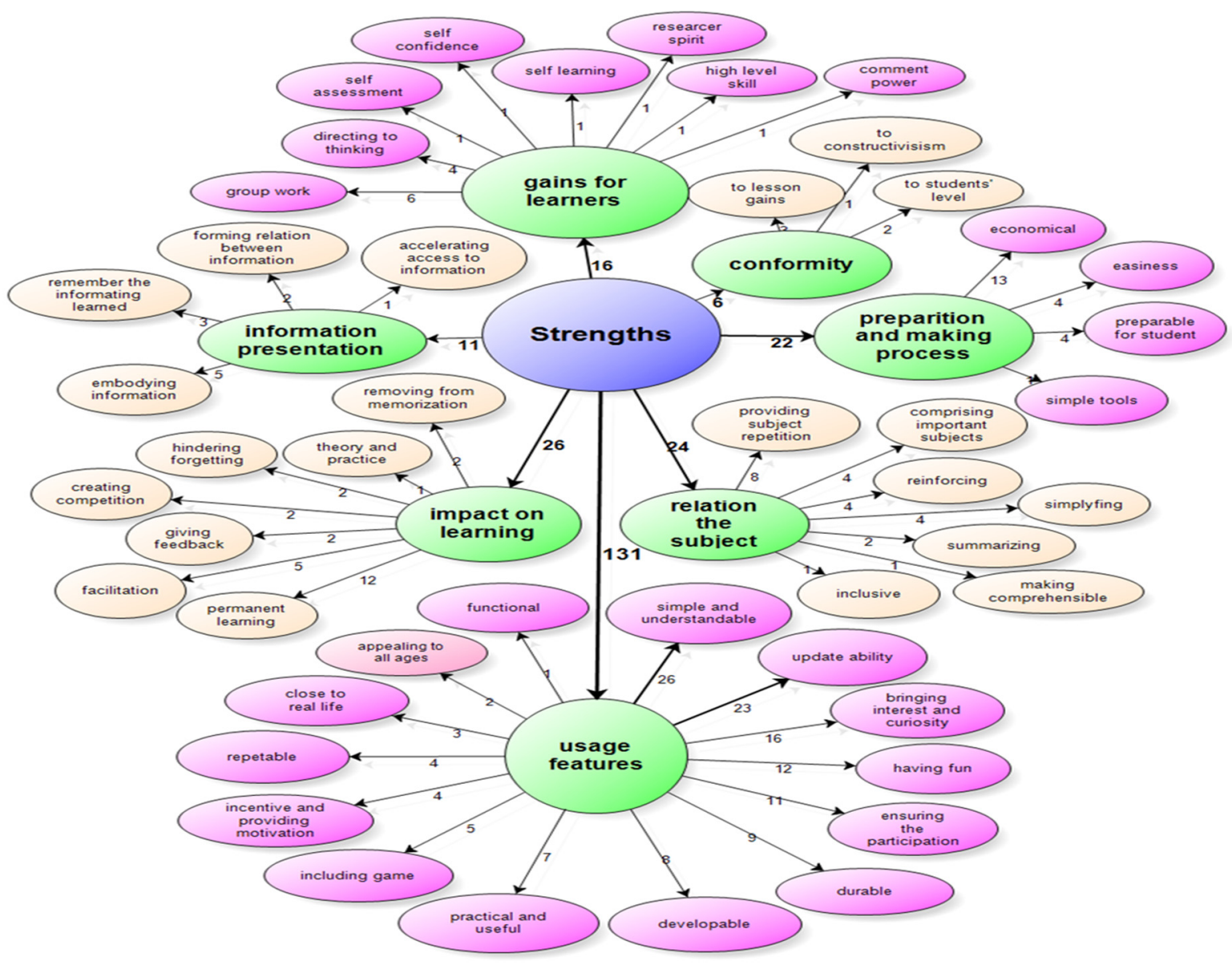

Figure 1. Prospective Teachers' Opinions on the Strengths of the Materials They Design 


\section{Results}

\subsection{Findings about the Strengths of Materials}

The views of the prospective teachers on the strengths of the instructional materials they design are collected under seven themes: "the characteristics of use" (f:131), "the effect on learning" "(f:26), "the relation with the subject" (f:24), "the preparation and construction process" (f:22), "the gains to the learners" (f:16), "the presentation of the information" (f:11) and "conformity" (f:6). In Figure 1, themes and sub-themes related to strengths are given by specifying frequencies (f).

In the theme of "the characteristics of use"; prospective teachers mentioned subjects such as the materials they designed. They are simple and understandable, they can be updated, they arouse interest and curiosity in the students, they have fun, they provide active participation of students, they should be strong, they can be developed, they should be practical and useful, they contain games, they provide motivation, they can be used repeatedly, they must be close to real life and each element of the material should be functional. They stated that the materials they designed had an impact on learning in terms of providing lasting learning, facilitating learning, giving feedback to the student, creating a competitive environment in learning, preventing forgetting, removing memorization and comprising both theory and practice. In the theme of "the preparation and making process" of the materials, the prospective teachers found the materials they designed strong on the grounds that they were financially economical, easy to build, even the students was able to prepare them on their own, and they contained simple materials which were easy to find. In the theme "the gains for learners", prospective teachers stated that the materials they designed could be effective in the development of the collaborative learning and development of the group work skills, directing students to thinking, providing self-confidence, self-evaluation, revealing self-learning and researcher spirit, improving high-level skills and interpretation. In the theme of the "information presentation", prospective teachers stated that the materials they designed materialized the information, reminded the previous information, provided a relationship between the information and the accelerated access to the information which are strong aspects of them. It has been pointed out in the theme of "the conformity" that the materials designed are conformable with the constructivist approach, course achievements and the level of the students. Some direct excerpts of the prospective teachers' views on the strengths of the materials they design are presented below with the photographs of the materials they designed:

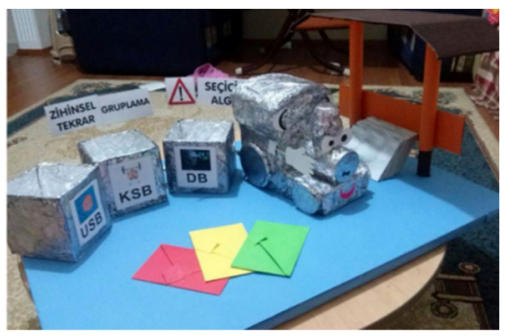

«In my material I tried to address more than one sense organ. ...I think it is a material that can be used easily in the teaching process. It provides permanent learning because it addresses to more sensory organs....... One of its most powerful aspects is that it is designed to perform in both lectures and at the end of the lesson. ((Prospective Teacher (P.S.) 29)) (Name of the material: Mind Train - Field: Psychology) Photograph 1: Mind Train

"First of all, I can show the philosophy visually and tangible by starting with the analogy of the house. The most important aspect is the formation of an environment where students can learn and discuss the subject with the lecture notes coming from the envelopes inside the windows. We can ask students to write what they know about the lesson by emptying the windows of the house. Or we can set the main theme and ask everyone to write down the ideas related to the theme determined at the end of the lesson and put them in the window. Thus, both an assessment is made and a permanent learning is

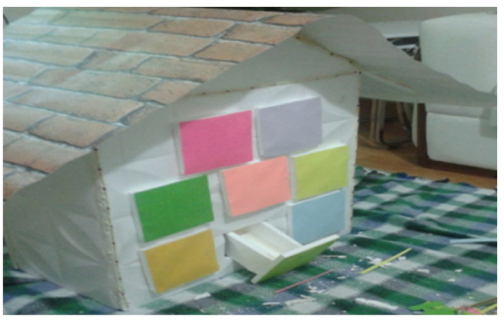
provided through brainstorming" (P.S. 41) (Material name: Philosophy Nest - Field: Philosophy) Photograph 2: Philosophy Nest

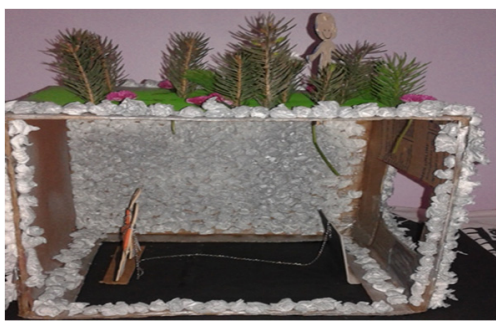

"....The analogy of Plato was characterized by characters in front of the students' eyes. They had the chance to see the real existence by embodying the story. Philosophers are often thought to be complex by students. With this material, they will see that they are not very incomprehensible, in fact, by trying to think and embody it somewhat. Since they saw just the analogy of Plato, they will have a better understanding of the subject. As they see the shadows falling on the cave wall in the subject themselves with a small fire, the subject will be shaped in memory" (P.S.40) (Material name: A look at the 
real being). Photograph 3: A look at the real being

"The most important feature of my material is that it is a known game. The Tabu game, which I adapted to the philosophy course, definitely draws the interest of the student in philosophy. In this game there is more than a sense of competition, so the student uses not only to find the concepts of philosophy but also uses his / her daily life to explain a philosophical concept. He also realizes how he /she can use philosophy in his daily life $>>$ (P.S. 35) (Material Name: Philosopher's trap. Photograph 4: Philosopher's trap

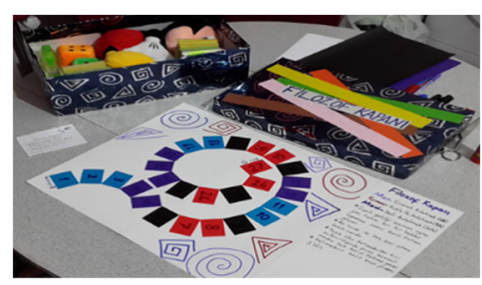

\subsection{Findings about Weaknesses of Materials}

The opinions of the prospective teachers about the weaknesses of the teaching materials have been collected under five themes: "Visual design errors" (f: 9), "physical use difficulties" (f: 9), "student participation and application deficiencies" (f: 6), "content problems" (f: 6) and " difficulties in preparation process " (f: 2). In Figure 2, themes and sub-themes related to weaknesses are given by specifying frequencies (f).

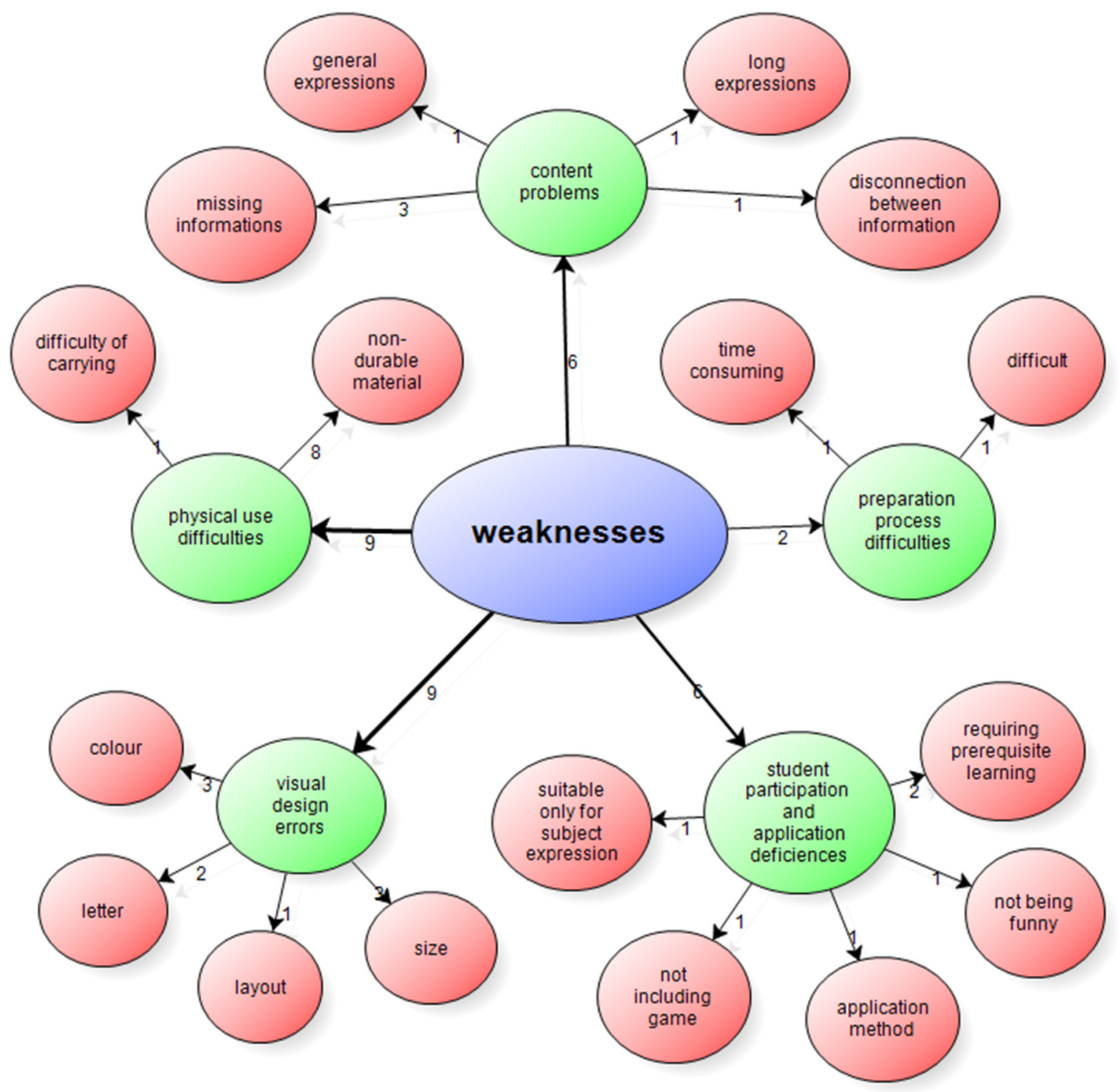

Figure 2. Prospective Teachers' Opinions about the Weaknesses of the Materials They Designed 
Errors related to visual design and physical use difficulties were the two most frequently repeated weaknesses of the materials stated by the prospective teachers. In terms of visual design, the prospective teachers considered themselves weak in terms of color selection, use of letters, location and dimensioning of elements. The use of non-durable materials in the instructional material and the difficulty of carrying the material were regarded as weaknesses of the material in terms of physical use. In the theme of "the deficiencies about the student participation and implementation", the prospective teachers emphasized the weaknesses in terms that the materials they designed were suitable only for subject expression, they did not include games, they were not funny, they required prerequisite learning and wrong application method. Prospective teachers, who pointed out that there are content problems in teaching materials, realized that general and long expressions are used, there is missing information and there is a disconnection between the informations. The fact that it is time consuming and difficult to prepare teaching material is also expressed as another weakness. Some of the opinions of the prospective teachers on the weaknesses are as follows:

"It was difficult to carry because the material was big. At the same time, adapting the material to other subjects will be time consuming". (P.S. 2)

"My material weaknesses are lack of adequate color and lack of classroom application". (P.S. 4)

"My material may be big for some students. But my purpose to make it big was to draw attention". (P.S. 9)

"Since the material will be used in the lecture, it is not very effective in encouraging the participation of the students". (P.S. 14).

"The preparation phase was a little bit troublesome". (P.S. 21)

"Maybe the weak point of my material is that it doesn't contain games". (P.S. 22)

"Non-durable feature of my material can be said as a weakness. It wasn't as durable as I wanted. In addition, because it was done in a very simple way, it may be difficult to address high school students". (P.S. 31).

"Before presenting the material, the student needs to have some knowledge about the subject. Or we can put pressure on the student and not attract the attention of the student when we present the material directly. This pushes the material back a little. Therefore, we need to explain the matter before presenting the material". (P.S. 33).

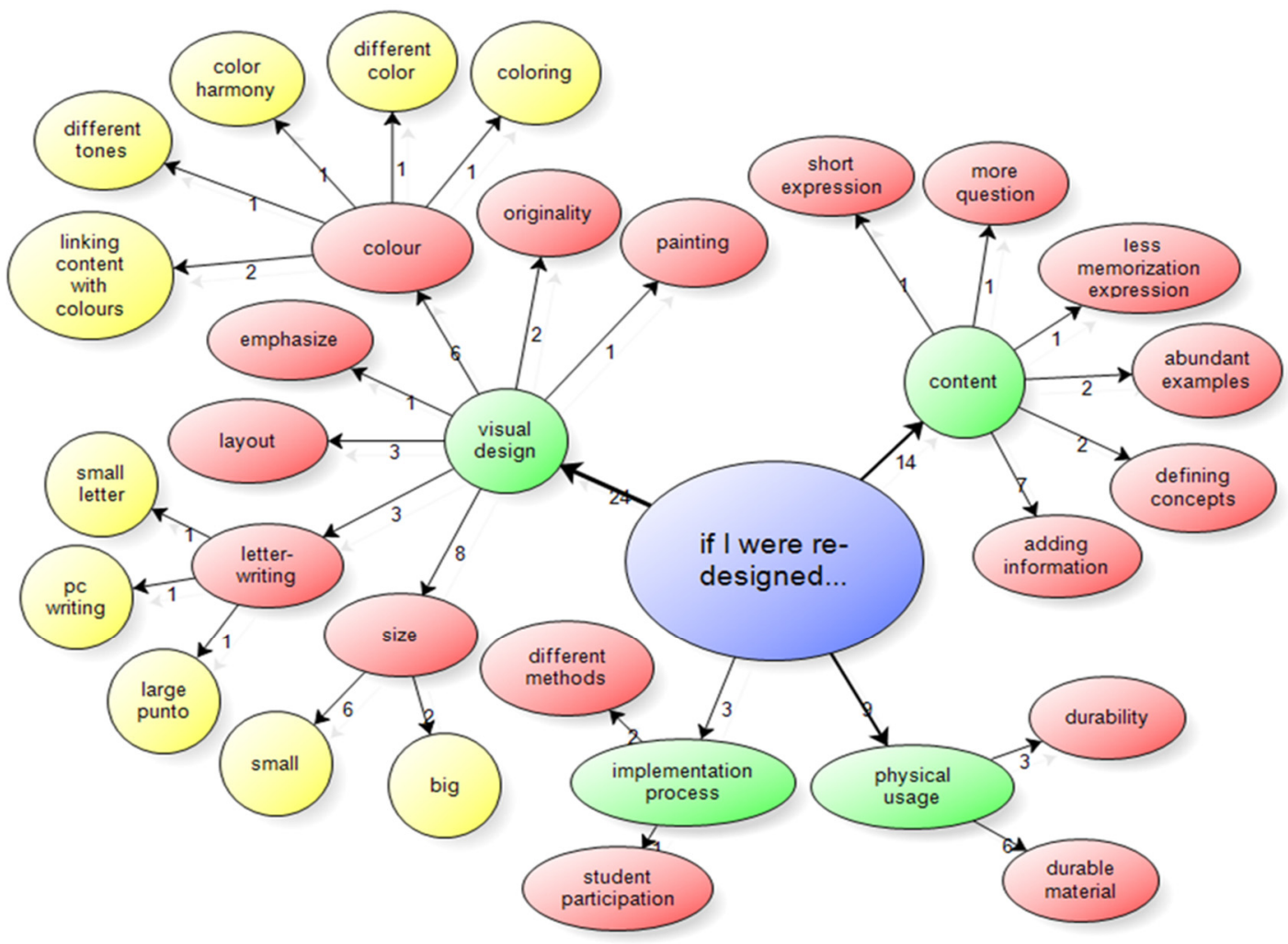

Figure 3. Arrangements for Prospective Teachers in Re-designing the Material 


\subsection{Findings Regarding Arrangements in Re-Designing the Material}

The opinions of the prospective teachers about the arrangements they would make if they designed the material again have been collected under four themes: "visual design" (f: 24), "content" (f: 14), "physical use" (f: 9) and "application process" (f: 3 ). In general, it is seen that the arrangements to be made in the case of redesign are expressed in terms of weaknesses. The theme and sub-themes of the opinions about to be made in the case of re-designing the material are given in Figure 3 by specifying the frequencies (f).

The prospective teachers stated that they will make lots of changes in visual design in case they design the material again. Within the scope of visual design, the prospective teachers, who were especially well on size and color, mentioned the subjects such as using different colors and tones, paying attention to color harmony, linking content with colors and including painting. In addition, making original designs, including images, better use of layout elements and emphasize, prefering small letters and large font sizes, etc. are among the other views on visual design. Adding information to the material in relation to the content while re-designing, in other words, making the material rich in information is the most expressed sub-theme. Apart from this sub-theme; using short expressions, taking abundant examples, reducing memorization expressions, comprising explanations of the concepts and more problems taking part in the material are the other things that should be changed in terms of content. It is considered important to use the material more effectively and to encourage student participation with different methods in relation to the implementation process. The prospective teachers stated that they would take care of using more durable materials in terms of physical use and of preparing more solid materials in general in the case of re-designing of the materials. Some of the opinions of the prospective teachers regarding the re-arrangements they would make in the re-designing of the materials are as follows:

"If I had re-prepared the material, I would give animation activities to the students. Thus, more effective and entertaining learning could be provided by practicing in-class practices on each mechanism". (P.S.4)

"I used wood, not cardboard, and designed the paper so that I could attach and remove them". (P.S.18)

"I'd do it more effortlessly. Because I realized that I was practicing as I did. In fact the material began with little material. As I did, they varied with original ideas. I mean, if I had redesigned it, I thought it was something more original". (P.S.19)

"If I redesigned the material, I would narrow the space further and increase the number of questions". (P.S.27)

"If I had redesigned my train, I would make it more solid and more realistic. So I'd get the student's attention. I would increase the number of philosophers. So I'd let them learn more philosophers and terms". (P.S.31)

"I would add silent expression to the narration category with puppet. Or I would prefer silent expression instead of puppetry". (P.S.35)

"I would have paid more attention to conformity of colors. The house I designed could be smaller. I would have the unit headers in the windows of the house bigger. So it can be read remotely". (P.S.41)

"Not very strong. I used to revise the endurance". (P.S.48).

\section{Discussion}

After the use of the instructional materials, the increase of the teaching efficiency and productivity is one of the most important elements (Güven, 2008: 168). Teachers should know the structure of the teaching materials and the principles of the effective use (Yangin, 2011: 44); Teachers should prepare the effective instructional materials using the knowledge of designing the instruction or guide the students' formation (Yanpar Yelken, 2011: 10). It is also important to know what types of materials can be used for the specific types of the target acquisitons. (Yanpar Yelken, $2011,11)$ because the teaching materials, regardless of the education level, have a significant effect on ensuring that students learn more easily and permanently in the classroom (Özer \& Tunca, 2014: 1).

Most of the studies about the teaching material issues in Turkey have been made in the form of the receipt of views on the ITMD course (Yazar, 2015; Güneş \& Aydoğdu İskenderoğlu, 2014; Bektaş, Nalçac1 \& Erçoşkun, 2009; Çalışoğlu, 2015). In addition, there is a research study of Usta (2015) which focused on the teaching materials and in which the prospective teachers are asked to determine the points they have taken into consideration while developing the teaching materials and what kind of difficulties they encounter. And, there is another research study of Özer and Tunca (2014) in which the views of the prospectives teachers were taken about the preparation and usage of materials. The views of the prospective teachers in the field of mathematics were taken on the use of teaching materials in mathematics lessons in the research of Ünlü (2017); and in a part of Öztürk and Zayimoğlu Öztürk’s 
(2015) research, the opinions of the history prospective teachers about the instructional materials they designed were taken. Significant findings and results have been obtained in all these studies. Unlike all of these studies, it is aimed at making a self-evaluation by the prospective teachers using the materials they designed. Thus, it was tried to reveal their strengths and weaknesses by looking at the materials they designed, in other words, their performance.

According to the research results; the prospective teachers explained the weaknesses of their materials in more detail than their strengths and expressed more views on their strengths. Some prospective teachers even stated that there were no weak aspects in their materials. However, there are also important assessments of the weaknesses of the materials. The difficulties which originated from the materials used, providing the durability of the material and the size of the material and which were encountered by the prospective teachers in preparing the materials in Özer and Tunca's (2014) study, and the weaknesses mentioned in this study are similar. In addition, in the study of Özer and Tunca (2014), the difficulty in identifying the original material design problems is consistent with the desire to make original designs in the present study. The opinions of the prospective teachers about designing the material as difficult, time consuming and difficult to transport the material in the study of Ünlü (2017) are among the aspects that the prospective teachers perceive as weak in the materials they designed in this research.

The logical relationship between the weaknesses of the materials and the arrangements to be made in the case of redesign is noteworthy. In fact, weaknesses and redesigning arrangements seem to be consistent with each other. For example; visual design mistakes are mentioned in weaknesses, and similarly the improvements of visual design in case of re-designing are discussed. Similarly, the views on the elimination of the weaknesses related to the content and physical use by redesigning overlap each other. In other words, the elimination of the weaknesses in these issues is reflected in redesigning. However, it does not seem possible to say the same thing in terms of the weakness of the student participation and implementation. The prospective teachers have identified and expressed the shortcomings in the student participation and practice; they could not develop enough ideas to redesign these weaknesses. Although it is mentioned about using different methods to improve the implementation process and encouraging student participation, it can be said that this theme lags behind the other themes both in terms of quantity and giving detailed opinions. Another result is that the prospective teachers who do not find any weakness in their material will naturally not do any difference in the case of redesign. On the other hand, an idea of the prospective teacher who recognizes the weaknesses such as "I'd do it more effortlessly. Because I realized that I was practicing as I did. In fact the material began with little material. As I did, they varied with original ideas. In other words, if I had redesigned, I think it would be something more original. (P.S.19)" draws attention to the importance of identifying the weaknesses and the fact that more creative materials can be produced. At the same time, the results indicate that the prospective teachers will be specialized in material design. For this reason, it can be suggested that the practices for designing the materials in teacher education should not be limited to a single course and that they should be spreaded to the whole education process. Again, the results of the research indicate that more emphasis should be placed on the application and student participation in material design. Apart from this; the promotion, implementation and evaluation of the materials designed in teacher education can be given together. This research is limited to self-evaluation only. In the future researches, the evaluation types such as peer evaluation and so on can be handled. This study has a qualitative structure. However, future research can be supported by quantitative methods to achieve more findings and results.

\section{References}

Acer, D. (2011). A study on the viewpoints of preschool teacher candidates on design of instructional materials course. Elementary Education Online, 10(2), 421-429.

Aslan, B. (2015). Öğretim teknolojileri ve materyal tasarımı dersinin İngilizce öğretmenlerinin mesleki kazanımlarına etkisi (Muğla İli Örneği). Master's thesis, Muğla Sitkı Koçman University, Muğla.

Apperson, J. M. Laws, E. L., \& Scepansky, J. A. (2006). The impact of presentation graphics on students' experience in the classroom. Computers and Education, 47(1), 116-126. https://doi.org/10.1016/j.compedu.2004.09.003

Audrey, R. M-Q. (2008). Utilizing powerpoint presentation to promote fall prevention among older adults. The Health Educator, 40(1), 46-52.

Bakaç, E., \& Özen, R. (2016). The relationship between preservice teachers' attitude towards instructional technology and material design course, creativity perceptions and self-efficacy beliefs. Abant Izzet Baysal University Journal of faculty of Education, 16(1), 41-61.

Bektaş, F., Nalçacı, A., \& Erçoşkun, H. (2009). Classroom teacher candidates' views on the attainments from 
"teaching technologies and material development" course. The Journal of Theoretical Educational Science (JTES), 2(2), 19-31.

Birinci, E. (2008). Materyal tasarımı ve geliştirilmesinde proje tabanlı öğrenmenin kullanılmasının öğretmen adaylarının eleştirel düşünme, yaratıcı düşünme ve bilimsel süreç becerilerine etkisi. Master's thesis, Zonguldak Karaelmas University, Zonguldak.

Birişçi, S., \& Karal, H. (2011). Effect of collaborative studies on prospective teachers' creative thinking skills while designing computer based material. Ahi Evran Üniversitesi Kırşehir Eğitim Fakültesi Dergisi, 12(2), 203-219.

Boud, D. (1995). Enhancing Learning Through Self-Assessment. London: Kogan Page.

Büyüköztürk, Ş., Kılıç Çakmak, E., Akgün, Ö. E., Karadeniz, Ş., \& Demirel, F. (2014). Bilimsel araştırma yöntemleri. Ankara: Pegem Akademi.

Cezayirli, M. (2014). Ortaokul 6. sinıflar için din kültürü ve ahlak bilgisi dersi materyal tasarımı. Master's thesis, Yüzüncü Yıl University, Van.

Cohen, J. (1992). Statistical power analysis. Current Directions in Psychological Science, 1(3), 98-101. https://doi.org/10.1111/1467-8721.ep10768783

Çalışoğlu, M. (2015). Opinion of preservice elementary teachers about the instructional technologies and material development course. Current Research in Education, 1(1), 23-32.

Çelik, L. (2012). Öğretim materyallerinin hazırlanması ve seçimi. In Demirel, Ö. \& Altun, E. (Ed.), Öğretim teknolojileri ve materyal tasarımı. Ankara: Pegem Yayıncılık.

Çilenti, K. (1984). Ĕgitim Teknolojisi ve Öğretim. Ankara: Kadığlu Matbaası.

Çoban, A., \& İleri, T. (2013). The level of social studies teachers' using teaching techniques and materials and the reasons of their inability to use them. Amasya Education Journal, 2(1), 194-213.

Dale, E. (1969). Audio visual methods in teaching (3rd ed.). Holt, Rinehart \& Winston, New York.

Demirel, Ö., \& Yağc1, E. (2012). Öğretim materyallerinin değerlendirilmesi. In Demirel, Ö. \& Altun, E. (Ed.), Öğretim Teknolojileri ve Materyal Tasarımı. Ankara: Pegem Akademi.

Falchikov, N. (1986). Product comparasions and rocess benefits of peer group and self assessment. Assessment and Evaluation in Higher Education, 11, 146-166. https://doi.org/10.1080/0260293860110206

Güneş, G., \& Aydoğdu İskenderoğlu, T. (2014). Attitudes of pre-service primary school mathematics teachers towards instructional technologies and material design lesson. GEFAD /GUJGEF, 34(3), 469-488.

Gürol, A., Yavuzalp, N., Bağçacı, F., \& Serhatlığlu, B. (2009). Öğretmen adaylarına göre eğitim fakültelerinde eğitim teknolojisi standartlart ve performans göstergelerinin uygulanma durumu (Firat Üniversitesi Örneği). Proceedings of 9th International Educational Technology Conference (IETC2009), 442 - 448.

Güven, S. (2006). The evaluation of teaching technologies and materials development course in terms of competencies it provides (a sample of Inönü University Faculty of Education). The Journal of Turkish Educational Sciences, 4(2), 165-179.

Güven, M. (2008). Öğretim materyali tasarım süreci. In Selvi, K. (Ed.), Öğretim Teknolojileri ve Materyal Tasarımı. Ankara: Anı Yayıncilık.

Harris, M. (1997). Self-assessment of language learning in formal settings. ELT Journal, 51(1), 12-20. https://doi.org/10.1093/elt/51.1.12

Johson, G., \& Howell, A. (2005). Attitude toward instructional technology following required versus optional webctusage. Journal of Technology and Teacher Education, 13(4), 643-654.

Kablan, Z., \& Topan, B. (2013). The effectiveness level of material use in classroom instruction: a meta-analysis study. Educational Sciences: Theory \& Practice, 13(3), 1629-1644.

Kolburan Geçer, A. (2010). Experience of technical teacher candidates towards teaching tecnologies and material development course. Yüzüncü Yıl Üniversitesi Eğitim Fakültesi Dergisi, VII(II), 1-25.

Kurtdede Fidan, N. (2008). Teachers' views with regard to the use of tools and materials in the primary level. The Journal of Theoretical Educational Science (JTES), 1(1), 48-61.

Kürüm, D. (2008). Öğretim materyallerinin değerlendirilmesi. In K. Selvi (Ed.), Öğretim Teknolojileri ve Materyal 
Tasarımı. Ankara: Anı Yayıncılık.

Merriam, S. B. (2013). Nitel Araştırma. (Çev. Ed. S. Turan). Ankara: Nobel Yayınları.

Mistar, J. (2011). A study of the validty and reliability of self-assessment. TEFLIN Journal: A publication on the teaching and learning of English, 22(1), 45-58.

Noonan, B., \& Randy, D. (2005). Peer and self-assessment in high schools. Practical Assessment Research and Evaluation, 10(17), 1-8.

Özer, Ö., \& Tunca, N. (2014). The opinion of pre-service teachers towards preparating and using of materials. Route Educational and Social Science Journal, 1(3), 214-229. https://doi.org/10.17121/ressjournal.130

Öztürk, İ. H. (2012). Design-based learning approach for developing ict-based teaching skills of history student-teachers. NWSA Education Sciences e-Journal of New World Sciences Acedemy, 7(3), 945-968.

Öztürk, T., \& Zayimoğlu Öztürk, F. (2015). The investigation of history teacher candidates' applications and opinions towards "instruction technologies and material design" course. E- Kafkas Journal of Educational Research, 2(3), 63-78.

Pierce, L. V. (2003). Assessing english language learners. Washington, D.C.: National Education Association.

Suydam, M.N., \& Higgins, J. L. (1977). Activity-based learning in elementary school mathematics: recommendations from research. ERIC Center for Science, Mathematics, and Environmental Education, Columbus, Ohio.

TDK. (2018). Türk dil kurumu. Retrieved from http://tdk.gov.tr

Turgut, M. F., \& Baykul, Y. (2010). Ĕ̆itimde ölçme ve değerlendirme. Ankara: Pegem Akademi.

Usta, E. (2015). The examination of prospective teachers' teaching materials development process in terms of visual and message design princıples. Gazi Journal of Education Sciences, 1(1), 1-14.

Uşun, S. (2012). Öğretim teknolojileri ve materyal tasarımı (2nd ed.). Ankara: Nobel Yayınları.

Ünlü, M. (2017). Pre-service mathematics teachers' views about using instructional materials in mathematics lessons. Journal of Theory and Practice in Education, 13(1), 10-34.

Yangın, S. (2011). Öğretim sürecinde kullanılan araçlar ve etkili kullanımı. In Küçük, M. (Ed.), Öğretim Teknolojileri ve Materyal Tasarımı. Ankara: Nobel Yayıncilik.

Yanpar, T., \& Yıldırım, S. (1999). Öğretim teknolojileri ve materyal geliştirme. Ankara: Anı Yayıncılık.

Yanpar, T. (2009). The effects of materials development based on "creativity activities within a group" on teacher candidates' portfolios. Education and Science, 34(153), 83-98.

Yanpar Yelken, T. (2011). Öğretim teknolojileri ve materyal tasarımı (10th ed.). Ankara: Anı Yayıncılık.

Yazar, T. (2015). Prospective teachers' opinions about instructional technologies and material design course. International Journal of Curriculum and Instructional Studies (IJOCIS), 5(9), 23-34.

Yıldırım, A., \& Şimşek, H. (2006). Nitel Araştırma Yöntemleri. Ankara: Seçkin Yayıncılık.

YÖK. (2007). Eğitim Fakültesi Öğretmen Yetiştirme Programları. Retrieved from http://www.yok.gov.tr/documents/10279/30217/E $\%$ C4\%9E $\%$ C4\%B0T $\% C 4 \% B 0 M+F A K \% C 3 \% 9 C L T E S \% C 4 \%$ B0\% $20 \% \mathrm{C} 3 \% 96 \% \mathrm{C} 4 \% 9 \mathrm{ERETMEN}+\mathrm{YET} \% \mathrm{C} 4 \% \mathrm{~B} 0 \% \mathrm{C} 5 \% 9 \mathrm{ET} \% \mathrm{C} 4 \% \mathrm{~B} 0 \mathrm{RME}+\mathrm{L} \% \mathrm{C} 4 \% \mathrm{~B} 0 \mathrm{SANS}+\mathrm{PROGRA}$ MLARI.pdf/054dfc9e-a753-42e6-a8ad-674180d6e382

\section{Note}

Note 1. This study was presented as the 1st International Teacher Education and Accreditation Congress. 